\title{
Short communication Avocado: Is it possible to produce two seedlings with one seed? ${ }^{1}$
}

\author{
Jackson Aparecido Chaves Souza $a^{2}$, Guilherme Carvalho Prates ${ }^{2}$, Joseane Turquete Ferreira ${ }^{2 *}$ (1) , \\ Guilherme Dumbá Monteiro de Castro ${ }^{2}$, Luiz Carlos Chamhum Salomão ${ }^{2}$
}

10.1590/0034-737X202067020009

\begin{abstract}
It was evaluated the possibility to produce two seedlings per avocado seed, through the separation of cotyledons. Two seed lots from two different ungrafted trees were evaluated. From the first tree were obtained 60 seeds, and 50 from the second. Half the seeds of each lot had their cotyledons separated and then whole seeds and half-seeds were sown in river sand. At 90 days after sowing, percentage of germinated seeds, shoot height, main root length, fresh and dry mass of shoots, roots and cotyledons were evaluated. From the first lot of seeds, there was $100 \%$ germination, both for the whole seeds and for the half-seeds. For all traits evaluated, higher mean values were observed for seedlings formed from whole seeds. In the second lot of seeds, $88 \%$ of germination was observed for whole seeds and $82 \%$ of germination for half-seeds. In this second lot, there were no significant differences between the seedlings formed from whole seeds and half-seeds for any of the characteristics evaluated, except for fresh and dry mass of cotyledons. Thus, it is possible to produce two seedlings or rootstocks with a single avocado seed, although this may slightly delay the development of the seedlings
\end{abstract}

Keywords: Persea americana Mill.; propagation; rootstocks; multiple stems.

\section{INTRODUCTION}

Avocado tree (Persea americana Mill.) is cultivated in almost all tropical and sub-tropical regions of the world. FAO data from 2017 indicates that Mexico is the main producer, with production of 2,029,886 tons, while Brazil presents a production of 213,041 tons and occupies the sixth position in the avocado world production (FAO, 2019). Avocado cultivation is widespread nearly in all Brazilian states, and São Paulo and Minas Gerais are the largest producers (IBGE, 2017).

In Brazil, avocado seedlings are mainly produced by grafting and rootstocks are obtained by seminiferous way. The anatomical study of the embryo axis of avocado seeds in the 'Hass' variety revealed that the vascular bundles start from a single embryo, with the branching of the epicotyl characterizing polystem and not polyembryony. Gurgel \& Soubihe Sobrinho (1951) also observed this phenomenon in grumixama, pitanga and uvaia seeds (Oliveira et al., 2010). As avocado has a single monoembryonic seed (Silveira et al., 2004), a large amount of fruits are needed for rootstock production and this process makes the orchard deployment more expensive. Considering that the seed, when germinating presents multiple stems, that is, it produces several adventitious shoots at the base of the main stem (Figure 1A), would it be possible to produce more than one seedling per seed?

This study aimed to evaluate the possibility of producing two seedlings per avocado seed, through the separation of the cotyledons.

\section{MATERIAL AND METHODS}

The experiment was carried out in a greenhouse without environmental control, in the Fruit Sector of the Department of Plant Science at the Universidade Federal de Viçosa.

Submitted on December $10^{\text {th }}, 2019$ and accepted on March 25 th, 2020.

${ }^{1}$ Project idealized by fruit growing trainees, seen field practices made by producers.

²Universidade Federal de Viçosa, Departamento de Fitotecnia, Viçosa, Minas Gerais, Brazil. jackson.chaves@ufv.br; guila1798@gmail.com; josyturchet@gmail.com; dumba12@hotmail.com; 1salomao@ufv.br

*Corresponding author: josyturchet@gmail.com 
The experimental area, located in the city of Viçosa, Minas Gerais, has the following geographical coordinates: 42 52'08' West longitude; 2045’27' South latitude and elevation of 663 meters. The climate of the region, according to the Köppen-Geiger classification, is Cwa type, humid subtropical, with cold and dry winter and hot and humid summer.

We evaluated two lots of fruits taken from avocado seeds obtained from two different ungrafted plants. The first lot consisted of 60 seeds obtained from plant number 1 and the second lot consisted of 50 seeds obtained from plant number 2. All fruits were harvested at a physiologically mature stage on 05/20/2018 and, after full ripening, seeds were extracted. Seeds were washed in running water, had their coats removed and were allowed to dry for three days. Following, half of the seeds in each lot had their cotyledons separated by hand twisting. All whole and half seeds were then treated with captan fungicide (Captan $250 \mathrm{Moly}^{\circledR}$ ) at a dose of $1.18 \mathrm{~g} / \mathrm{kg}$ of seeds and, then, sown in plastic containers with holes in the bottom, which were kept on benches, in a greenhouse. The substrate used was river sand of medium texture, which was kept moist until close to field capacity. The whole seeds and half seeds were completely immersed in sand, with the flat side facing down. The sowing took place on 05/29/2018.

A completely randomized design with two treatments (whole seeds and half seeds) was used. Each seed lot was considered a separate experiment. For the first lot, there were 30 repetitions for whole seeds and 60 for half seeds and for the second lot, 25 repetitions for whole seeds and 50 for half seeds. Each whole seed or half seed constituted one sample unit.

Evaluations took place 90 days after sowing, when the seedlings were removed from the substrate and the roots were washed in running water. Percentage of germinated seeds, shoot height, length of the largest root, fresh and dry weight of shoot, root and cotyledons were evaluated. Shoot height and root length were obtained with the aid of a millimeter ruler. Fresh and dried weight were obtained by weighing on a precision electronic balance and the samples were dried in a drying oven at $70{ }^{\circ} \mathrm{C}$ up to constant weight.

Data were analyzed with the aid of the software System for Statistical and Genetic Analysis - SAEG 9.1 (SAEG, 2007) and the treatments were compared by the F test at a $5 \%$ probability level.

\section{RESULTS AND DISCUSSION}

From the first seed lot there was $100 \%$ germination for both whole and half seeds (Figure 1A and 1B). Significant differences were observed for all characteristics evaluated, with the highest averages obtained with whole seeds (Table 1). In this case, the results suggest that the separation of cotyledons caused delay in seedling development.

In the second seed lot, $88 \%$ germination was observed for whole seeds and $82 \%$ germination for half seeds (Table 2). The lower germination percentages in relation to the first lot are justified by the greater unevenness of seeds in
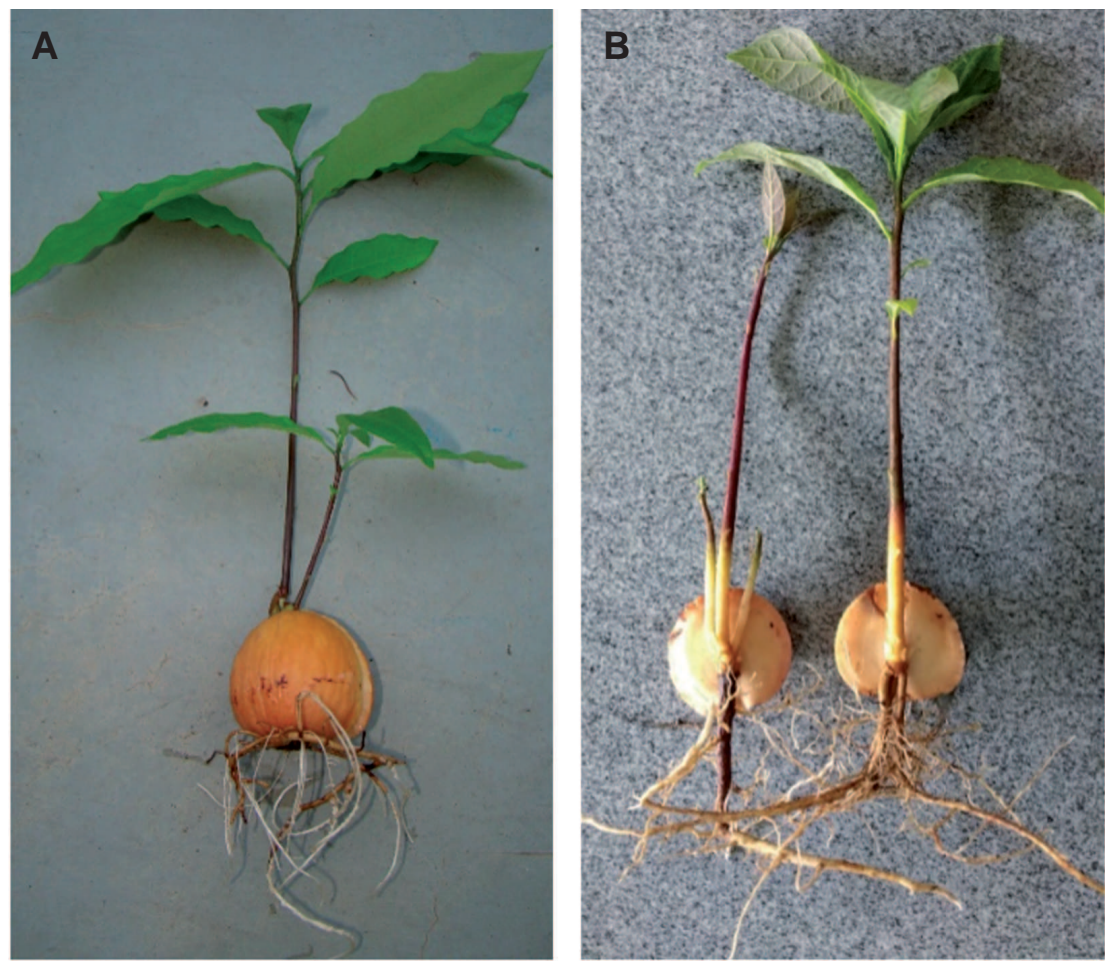

Figure 1: Multiple stems in Avocado seed (A) and seedlings germinated from two half seeds (B). Viçosa - MG, 2018. 
Table 1: Germination percentage and physical characteristics of seedlings generated from the first lot of avocado seeds ${ }^{1}$. Viçosa - MG, 2018

\begin{tabular}{lccccccccc}
\hline Seed & $\begin{array}{c}\text { Germ. } \\
(\%)\end{array}$ & $\begin{array}{c}\text { Shoot } \\
\text { height } \\
(\mathbf{c m})\end{array}$ & $\begin{array}{c}\text { Root } \\
\text { length } \\
(\mathbf{c m})\end{array}$ & $\begin{array}{c}\text { FW } \\
\text { shoot } \\
(\mathbf{g})\end{array}$ & $\begin{array}{c}\text { FW } \\
\text { root } \\
(\mathbf{g})\end{array}$ & $\begin{array}{c}\text { FW } \\
\text { cotyledon } \\
(\mathbf{g})\end{array}$ & $\begin{array}{c}\text { DW } \\
\text { shoot } \\
(\mathbf{g})\end{array}$ & $\begin{array}{c}\text { DW } \\
\text { root } \\
(\mathbf{g})\end{array}$ & $\begin{array}{c}\text { DW } \\
\text { cotyledon } \\
(\mathbf{g})\end{array}$ \\
\hline Whole & 100 & $19.83 \mathrm{a}$ & $16.93 \mathrm{a}$ & $7.73 \mathrm{a}$ & $4.90^{\mathrm{a}}$ & $69.70 \mathrm{a}$ & $1.85 \mathrm{a}$ & $0.89 \mathrm{a}$ & $18.55 \mathrm{a}$ \\
Half & 100 & $14.25 \mathrm{~b}$ & $14.22 \mathrm{~b}$ & $3.30 \mathrm{~b}$ & $2.40 \mathrm{~b}$ & $37.79 \mathrm{~b}$ & $0.86 \mathrm{~b}$ & $0.43 \mathrm{~b}$ & $11.41 \mathrm{~b}$ \\
\hline $\mathrm{CV}(\%)$ & & 36.22 & 24.80 & 51.43 & 54.67 & 15.77 & 54.14 & 25.73 & 104.19 \\
\hline
\end{tabular}

The averages with different letters in the column differ from each other at the $5 \%$ probability level by the $\mathrm{F}$ test. ${ }^{1}$ The first lot refers to the set of 30 whole seeds and 60 half seeds. FW: Fresh weight; DW: Dry weight.

Table 2: Germination percentage and physical characteristics of seedlings generated from the second lot of avocado seeds ${ }^{1}$. Viçosa MG, 2018

\begin{tabular}{lccccccccc}
\hline Seed & $\begin{array}{c}\text { Germ. } \\
(\%)\end{array}$ & $\begin{array}{c}\text { Shoot } \\
\text { height } \\
(\mathbf{c m})\end{array}$ & $\begin{array}{c}\text { Root } \\
\text { length } \\
(\mathbf{c m})\end{array}$ & $\begin{array}{c}\text { FW } \\
\text { shoot } \\
(\mathbf{g})\end{array}$ & $\begin{array}{c}\text { FW } \\
\text { root } \\
(\mathbf{g})\end{array}$ & $\begin{array}{c}\text { FW } \\
\text { cotyledon } \\
(\mathbf{g})\end{array}$ & $\begin{array}{c}\text { DW } \\
\text { shoot } \\
(\mathbf{g})\end{array}$ & $\begin{array}{c}\text { DW } \\
\text { root } \\
(\mathbf{g})\end{array}$ & $\begin{array}{c}\text { DW } \\
\text { cotyledon } \\
(\mathbf{g})\end{array}$ \\
\hline Whole & 88 & $16.41 \mathrm{a}$ & $14.89 \mathrm{a}$ & $5.22 \mathrm{a}$ & $2.49 \mathrm{a}$ & $69.70 \mathrm{a}$ & $1.45 \mathrm{a}$ & $0.51 \mathrm{a}$ & $18.72 \mathrm{a}$ \\
Half & 82 & $15.26 \mathrm{a}$ & $12.74 \mathrm{a}$ & $3.93 \mathrm{a}$ & $1.99 \mathrm{a}$ & $37.79 \mathrm{~b}$ & $1.03 \mathrm{a}$ & $0.40 \mathrm{a}$ & $10.02 \mathrm{~b}$ \\
\hline $\mathrm{CV}(\%)$ & & 62.82 & 42.84 & 89.78 & 92.24 & 42.55 & 106.53 & 57.28 & 100.68
\end{tabular}

The averages with the same letter in the column do not differ from each other at the 5\% probability level by the $\mathrm{F}$ test. ${ }^{1}$ The second lot refers to the set of 25 whole seeds and 50 half-seeds. FW: Fresh weight; DW: Dry weight.

this lot, since plant number 2 is earlier in terms of fruit development and fruits were harvested at the end of the crop of that mother plant. Nevertheless, this germination percentage can be considered satisfactory, since it is comparable to the percentages obtained by Paixão et al. (2016) and Oliveira et al. (2010). Regarding the other characteristics evaluated, no significant differences were observed, except for fresh and dry weight of cotyledons (Table 2). This result was expected because whole seeds (two cotyledons) and half seeds (one cotyledon) were compared.

The good results obtained for the germination of seeds extracted from fruits of two genetically different avocado trees suggest that the cotyledon separation technique can be used independently of the cultivar used as rootstock.

The results obtained suggested that when the seed cotyledons are separated, a fraction of the meristematic tissue remains attached to each of them, which allows the formation of two seedlings from one seed, as suggested by Traub \& Auchter (1933a, 1933b), which are the only references found on the subject. Normally, when the seed remains whole, the main budding stands out, inhibiting the development of others (Figure 1A).

In the first seed lot, the separation of cotyledons resulted in delayed seedling development, as also observed by Traub \& Auchter (1933a, 1933b), which may be explained by reducing the amount of reserve available for the seedling. This explanation is confirmed by the fact that Paixão et al. (2016) observed a direct relationship between the seeds mass of 'Collinson' avocado and the number of shoots per seed.
Traub \& Auchter (1933a, 1933b) also stated that it is possible to divide each cotyledon into two parts, allowing the formation of up to four seedlings per seed. However, they did not present any numerical results about their experiments.

\section{CONCLUSION}

Thus, it is concluded that it is possible to produce two seedlings or rootstocks with a single avocado seed, enabling the reduction of costs in the implantation of avocado orchards, although this may cause a short delay in seedling development.

\section{CONFLICT OF INTEREST}

The authors declare that there is no conflict of interest.

\section{REFERENCES}

FAO - Organização das Nações Unidas para a Agricultura e Alimentação (2019) FAOSTAT. Divisão de estatística. Available at: 〈http://www.fao.org/faostat/en/\#data/QC>. Accessed on: August 09 ${ }^{\text {th }}, 2019$.

IBGE - Instituto Brasileiro de Geografia e estatística (2017) Área destinada à colheita, área colhida, quantidade produzida, rendimento médio e valor da produção das lavouras permanentes. Available at: 〈https://sidra.ibge.gov.br/tabela/1613\#resultado〉. Accessed on: August 09 ${ }^{\text {th }}, 2019$.

Gurgel JTA \& Soubihe Sobrinho J (1951) Poliembrionia em mirtáceas frutíferas. Bragantia, 11:141-163.

Oliveira IVM, Costa RS, Môro FV, Martins ABG \& Silva RRS (2010) Caracterização morfológica do fruto, da semente e desenvolvimento pós-seminal do abacateiro. Comunicata Scientiae, 1:69-73. 
Paixão MVS, Lopes JC, Schmildt ER, Alexandres RS \& Meneghelli CM (2016) Avocado seedlings multiple stems production. Revista Brasileira de Fruticultura, 38:e-221.

SAEG (2007) SAEG: Sistema para Análises Estatísticas e Genéticas. Versão 9.1. Viçosa, Fundação Arthur Bernardes / UFV. CDROM.

Silveira SV, Souza PVD \& Koller OC (2004) Propagação vegetativa de abacateiro por estaquia. Revista Brasileira de Fruticultura, 26:191-192.
Traub HP \& Auchter EC (1933a) Propagation experiments with avocado, mango, and papaya. Proceedings of the American Society for Horticultural Science, 30:382-386.

Traub HP \& Auchter EC (1933b) Sprouting and grafting fractional parts of avocado embryos with attached cotyledonous material. Science, 78:389-390. 